Petrović Aleksandra*

https://orcid.org/0000-0002-8062-9751
UDK: 343.346-051

Review article

DOI: $10.5937 / \mathrm{ptp} 2104115 \mathrm{P}$

Received: 24.08.2021.

Approved on: 14.10.2021.

Pages: $115-127$

\title{
THE EXOGENOUS CHARACTERISTICS OF TRAFFIC DELINQUENTS
}

\begin{abstract}
The exogenous characteristics of traffic participants, such as: alcoholism, fatigue and psychoactive substances, have a significant impact on a safe behaviour in traffic, especially the motor vehicle drivers. In that sense, they represent the factors that can directly influence the unsafe behaviour in traffic. The influence of the exogenous characteristics on a safe behaviour of traffic participants has been analysed on the basis of the statements in documents as well as the results of numerous empirical studies. For the purposes of this paper, there have been selected and analysed the statistical data on the influential factors of traffic accidents for the period from 2010 to 2019 in Republic of Serbia. After reviewing the statistical data, both a qualitative and quantitative content analyses were performed. In addition to the statistical method, there were also used the content analysis methods, empirical method, descriptive method, comparative methods, as well as deduction and induction methods, in order to analyse the trend and presence of these influential factors of traffic accidents in Republic of Serbia. The statistical data being processed in this paper, originated from the database of the Traffic Safety Agency of Republic of Serbia. The results of the research show the extent to which the exogenous characteristics affect a safe behaviour of traffic participants, as well as the severity of the consequences of traffic accidents. Observed individually, the listed characteristics have a different intensity of influence on a safe behaviour in traffic. In this regard, from the external
\end{abstract}

\footnotetext{
* PhD, The University of Pristina in Kosovska Mitrovica, The Faculty of Technical Sciences in Kosovska Mitrovica, Serbia, e-mail:aleksandra.petrovic@pr.ac.rs

(c) () (C) 2021 by the authors. This article is an open access article distributed under the terms and conditions of the Creative Commons Attribution (CC BY) license (https://creativecommons. org/licenses/by/4.0/).
} 
characteristics of traffic delinquents, the most common is the drunk driving as an influential factor, which especially affects the severity of traffic accidents in Republic of Serbia.

Keywords: traffic delinquents, traffic accidents, criminal offenses, traffic safety

\section{Introduction}

There is no single understanding in science about the common characteristics of traffic delinquents, despite the existence of numerous typologies. Moreover, one gets the impression that in this form of delinquency, the typologies are additionally relativized. This is indicated by the fact that the largest part of the population of a community participates in everyday life in traffic, and that both, in the role of a delinquent and in the role of a victim of traffic offenses, any citizen or participant in traffic can be found. Due to the mass nature of this negative social phenomenon, it is much more difficult to notice characteristics that affect delinquent behaviour on an individual level (Petrović, 2019, p. 46). Summarizing the results of previous research, we can identify those characteristics that are more common and typical in traffic delinquents than some others, and that affect the (un) safe behaviour of traffic participants. Thus, the mechanisms of behaviour of traffic delinquents can be explained to some extent, but not completely.

The specifics of traffic delinquency as a special type of criminal behaviour derive from the characteristics of traffic delinquents. Speaking about the aetiology of traffic offenses, i.e. criminogenic factors, it was pointed out that in most cases, the cause of a traffic accident lies in a person (Petrović, 2021, p. 115). In criminological research into the causes of traffic delinquency, it is especially important to determine the influential factors that cause behaviours that deviate from socially desirable ones. Briefly, it is necessary to point out those characteristics of traffic participants (endogenous, exogenous, sociodemographic, etc.), which lead to socially deviant behaviours and the commission of traffic offenses. The importance of studying these characteristics is reflected in their use to find adequate measures to influence the change in the behaviour of traffic participants in order to prevent traffic delinquency (Džunić, 2018, p. 54). 


\section{Influence of exogenous characteristics on traffic safety in the Republic of Serbia}

Exogenous characteristics (drunk driving, fatigue and psychoactive substances) have a significant impact on the safe behaviour of traffic participants. In that sense, they represent factors that can directly influence safe behaviour in traffic. The influence of exogenous characteristics on the safe behaviour of traffic participants was analysed on the basis of statements in documents, results of empirical research and data on their presence as influential factors of traffic accidents in the Republic of Serbia. It is especially important to point out that the data in the ten-year period from the beginning of the application of "new" legal provisions in the field of traffic safety, tightening of penal policy and introduction of a wider range of preventive measures to improve traffic safety are analysed.

\section{Driving under the influence of alcohol}

Alcohol is the only psychoactive substance consumption of which establishes a consistent and strong connection with criminal behaviour that contains elements of violence. In addition to reducing speed and using seat belts, special attention should be paid to driving under the influence of alcohol in order to improve the level of traffic safety.

Research has shown that alcohol affects driving ability and increases driver reaction time. The ability to process information and make relevant decisions is weak, which is why driving under the influence of alcohol affects risky behaviour in traffic. Driving under the influence of alcohol significantly reduces the ability of drivers, both perceptual and motor, as well as cognitive and memory. It has been medically proven that alcohol is resorbed very quickly in the body through the bloodstream (on average in 30-60 minutes), while the elimination of alcohol from the blood is a much slower process, averaging $0.017 \%$ per hour (NHTSA, 1994, p. 4). The American National Institute on Alcohol Abuse and Alcoholism conducted a study of the effect of alcohol on behaviour and found that alcohol causes a high level of aggression and violent behaviour (NIAAA, 1997). There is a direct link between the amount of alcohol consumed and the negative effects on the driver's ability. The risk of causing traffic accidents and death as their consequences increases proportionally with a higher concentration of alcohol in the blood. The concentration of alcohol in the blood over 1.5 per mille increases the risk of drivers' participation in traffic accidents by 20 to 60 times, in relation to the concentration of alcohol in the blood up to 0.5 per mille (Lipovac, 2008, p. 121). Alcohol is considered to be one of the most 
significant causes of accidents with casualties (Connor, Norton, Ameratunga, \& Jackson, 2004, p. 337). One of the big misconceptions is that consuming a small amount of alcohol, "a glass of brandy up to two", does not affect the driver's behaviour. Empirical research and practice have shown that, even with lower blood alcohol concentrations, a person has a poor assessment of ability, self-criticism decreases, self-confidence grows, drivers drive faster and riskier (Ronen et. al., 2004, p. 2, 6). These effects are also present at low blood alcohol concentrations up to 0.2 per mille, and when the concentration is over 1.4 per mille, the driver is considered completely incapable of driving. In the total number of traffic accidents caused by driving under the influence of alcohol, the largest number were caused by drivers whose blood alcohol concentration was relatively low (Milić, 2007, p. 270). A positive correlation was found between the delinquent behaviour of young drivers and alcohol dependence. In addition, far more men than women were injured in traffic accidents due to driving under the influence of alcohol (Petrović et al., 2020, p. 483).

The Law on Traffic Safety on the Roads of the Republic of Serbia (hereinafter: ZoBS) provides for zero tolerance to alcohol for drivers with a trial driver's license and professional drivers. The limit of the allowed amount of alcohol in the blood for amateur drivers was 0.3 per mille in 2010 , and the amendments to the ZoBS from 2018 were reduced to 0.2 per mille (Road Traffic Safety Act, 2009). In the period from 2010-2019. year in the Republic of Serbia, 28,824 traffic accidents were registered, in which the influencing factor was an alcoholic condition. The percentage of this influential factor in traffic accidents shows a slight upward trend in the analysed period, Graph 1.1.

Graph 1.1 - Percentage of alcohol status as an influential factor in traffic accidents in the Republic of Serbia in the period from 2010 to 2019

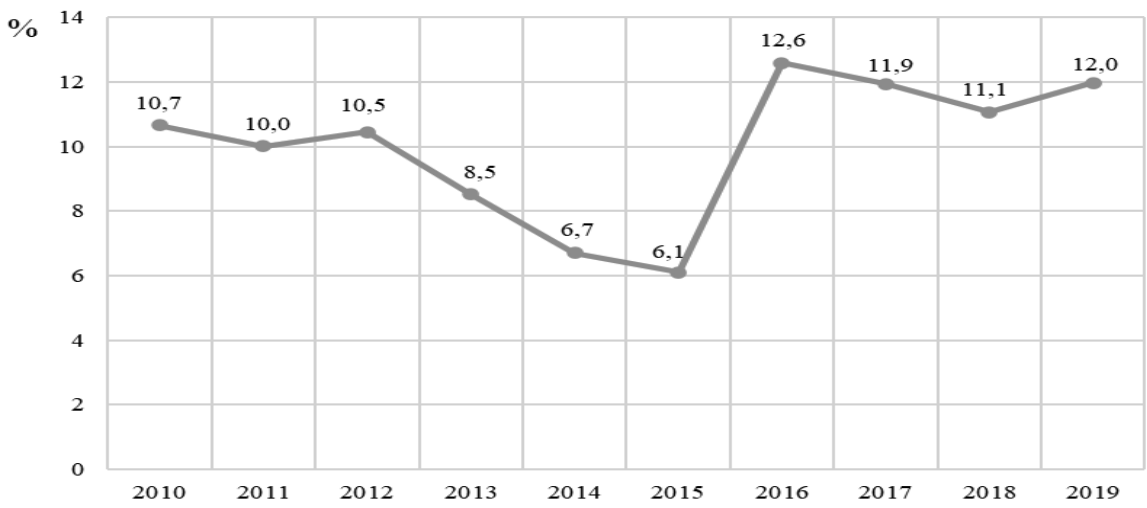

Author's research 
In 2010, 2,753 traffic accidents were registered, where the influential factor was an alcoholic condition (10.7\%), and in 2019, 3,091 traffic accidents $(12.00 \%)$. Out of the total number of registered traffic accidents caused due to alcohol, the lowest number was recorded in 2015, 1,575 traffic accidents (6.1\%), and the highest in 2016, 3,250 traffic accidents (12.6\%), Table 1.1.

Table 1.1 - Registered traffic accidents with dead and injured persons and the total number of traffic accidents in which the influencing factor is an alcoholic state, in the period from 2010 to 2019 in the Republic of Serbia

\begin{tabular}{|c|c|c|c|c|c|c|}
\hline \multirow{2}{*}{ Year } & \multicolumn{2}{|c|}{ TA with dead } & \multicolumn{2}{c|}{ TA with injured } & \multicolumn{2}{c|}{ Total number of } \\
\cline { 2 - 7 } & No. & $\%$ & No. & $\%$ & No. & $\%$ \\
\hline 2010 & 45 & 7,49 & 1054 & 8,86 & 2753 & 10,66 \\
\hline 2011 & 51 & 8,49 & 984 & 8,28 & 2583 & 10,00 \\
\hline 2012 & 39 & 6,49 & 1002 & 8,43 & 2700 & 10,46 \\
\hline 2013 & 52 & 8,65 & 894 & 7,52 & 2200 & 8,52 \\
\hline 2014 & 25 & 4,16 & 791 & 6,65 & 1733 & 6,71 \\
\hline 2015 & 35 & 5,82 & 768 & 6,46 & 1575 & 6,10 \\
\hline 2016 & 99 & 16,47 & 1594 & 13,41 & 3250 & 12,59 \\
\hline 2017 & 82 & 13,64 & 1631 & 13,72 & 3082 & 11,93 \\
\hline 2018 & 80 & 13,31 & 1524 & 12,82 & 2857 & 11,06 \\
\hline 2019 & 93 & 15,47 & 1648 & 13,86 & 3091 & 11,97 \\
\hline Total & 601 & 2,33 & 11890 & $46,04 \%$ & 25824 & 100 \\
\hline
\end{tabular}

Source: Database of the Traffic Safety Agency of the Republic of Serbia

As a consequence of traffic accidents caused by an alcoholic state, in $46.04 \%$ of cases there are accidents with injured persons, and in $2.33 \%$ of cases there are accidents with dead persons (on average in the period from 2010-2019). In that sense, it is important to emphasize that the results for the analysed period show that the consequences of the total number of registered traffic accidents in the Republic of Serbia make up 35.44\% of accidents with injuries, and $1.47 \%$ of accidents with deaths (Petrović, 2021, p. 222). If these data are compared, a significantly higher percentage of casualties in traffic accidents is observed, in which the influencing factor is an alcoholic state. This 
statement speaks in favour of the claims in the literature that an alcoholic state also affects the severity of the consequences of traffic accidents.

\section{Fatigue}

Fatigue can greatly affect safe driving behaviour. Some authors consider it an equally important accident-causing factor, as well as acute alcoholism, especially in professional drivers (Atanacković et al., 1987, p. 232). Fatigue is one of the important accident-causing factors in traffic, whose action leads to psychological and physical fatigue in drivers, which complement each other. It has been identified as a contributing factor to causing traffic accidents in a wide range of circumstances, with the implication that tired people are less likely to achieve safe performance and activities in traffic. According to Hajduković (1970), "Fatigue is a specific psychological state of the organism, caused by an activity, which usually manifests itself in a decrease in work efficiency"(cited by: Atanacković et al., 1987, p. 229).

Symptoms of fatigue, given the specific impact on driving ability, can relate to the psychological component, fatigue reflexes, automatic movements and muscle components. In addition, fatigue leads to slowing of reflexes and automatic movements. Research has shown that due to fatigue, the psychic second is prolonged, with the appearance of unnecessary and excessive movements and actions. At the beginning of fatigue there is a decrease in attention, which then weakens faster and faster. In a word, the driver's ability to safely drive a motor vehicle decreases sharply, drowsiness occurs, and there is a lack of control of traffic behaviour that results in errors. The literature states that the impact of this cause of traffic accidents is underestimated, because there are no reliable ways to determine in each specific case whether the traffic accident occurred due to driver fatigue (Stanojević, 2013, p. 72). According to the results of empirical research, the impact of fatigue typically ranges from $1-3 \%$ of the causes of all accidents (Lyznicki at al., 1998, p. 1910) and even up to $20 \%$ of accidents that occur on major roads and highways (Horne and Reyner, 1995, p. 565), while some research has shown that this share exceeds $30 \%$ (Stutts et al., 2006, p. 94).

In the structure of traffic accidents in the Republic of Serbia, fatigue as an influential factor was registered in 2,041 traffic accidents in the period from 2010-2019. years. The number of traffic accidents due to fatigue increased in the analysed period, as shown in Graph 1.2. 
Graph 1.2 - Percentage presentation of fatigue as an influential factor in traffic accidents in the Republic of Serbia in the period from 2010 to 2019

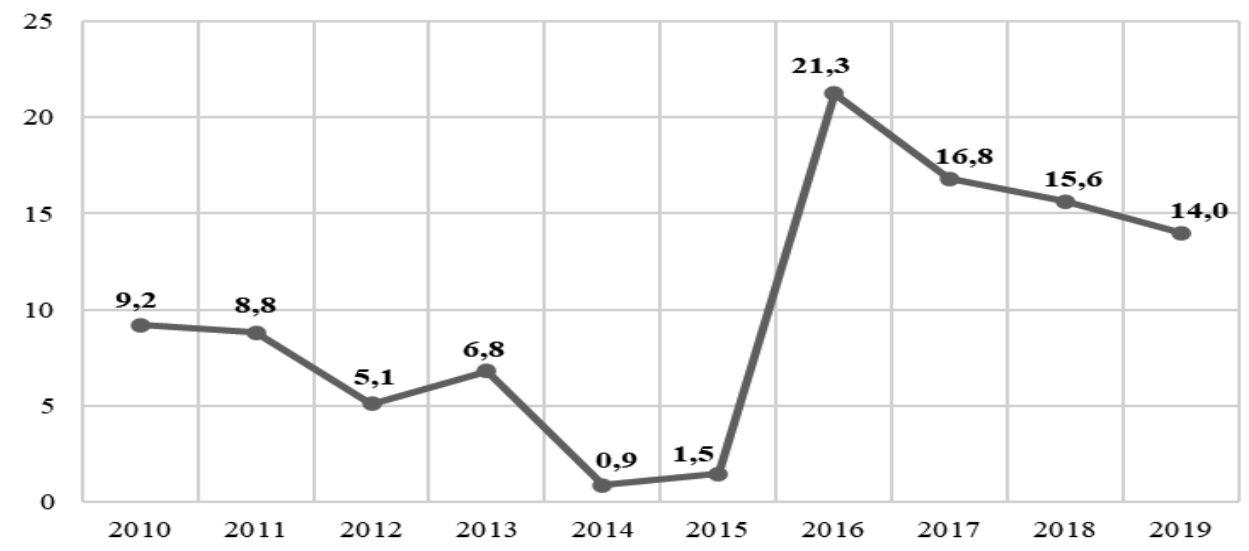

Author's research

From 2010 to 2014, a decrease in the number of traffic accidents in which fatigue was registered as an influential factor can be noticed. Since 2016, there has been a sharp increase in the percentage $(21.26 \%)$ of this influential factor, and then a decrease in the percentage in the following years until 2019, when it was $14.01 \%$. It is assumed that this sudden change is the result of recording a larger number of influential factors in traffic accidents since 2016 (several influential factors are recorded instead of one). ${ }^{1}$

\section{Psychoactive substances}

Psychoactive substances affect the psychophysical ability of road users. These include drugs, drugs or other chemical substances that may affect the ability to participate safely in traffic. "Tabletomania" is a term that is often used nowadays. It signifies the fact of mass and uncontrolled consumption of drugs. While the harmful effects of alcohol on the psychophysical abilities of drivers have been thoroughly examined and well known, it is less known that consuming a large number of drugs can have a much more intense impact on damaging some body functions necessary for safe driving. It is estimated

\footnotetext{
${ }^{1}$ These data were also influenced by the change in the method of recording the causes of traffic accidents in 2016, since several influential factors that contributed to its occurrence are recorded for each traffic accident, and not just one as was practiced until then. Variation in the data indicates the relativity of indicators of changes in the entire period, especially when we talk about fatigue, because fatigue was often a "neglected" factor in determining the cause of traffic accidents.
} 
that in developed countries, about $20 \%$ of drivers drive a vehicle under the influence of drugs (Stanojević, 2013, p. 72). The results of meta-analyses on the effect of the use of drugs as a cause of traffic accidents, showed that users of tranquilizers have a 1.59 times higher probability of experiencing a traffic accident (Dassanayake, Michie, Carter \& Jones, 2011, p. 58).

The use of drugs addictive substances, causes more severe disorders of psychophysical abilities in drivers, compared to alcohol or drugs. It causes serious disorders of mental and physical abilities, which are reflected in the loss of control over one's own actions, disorders of perception in time and space, hallucinations, etc. Numerous studies have confirmed that drug use significantly increases the risk of being involved in traffic accidents. The data indicate that in the population of drivers in Europe, the prevalence of the use of illicit drugs is $1-5 \%$, while the permitted drugs that have a harmful effect on driving are widespread from 5-10\% (Walsh et al., 2013, p. 250).

Psychoactive substances were registered as an influential factor in 374 traffic accidents in the Republic of Serbia in the period from 2010 to 2019. years. Their percentage representation by years is shown in Graph 1.3.

Graph 1.3 - Percentage presentation of psychoactive substances as an influential factor in traffic accidents in the Republic of Serbia in the period from 2010 to 2019

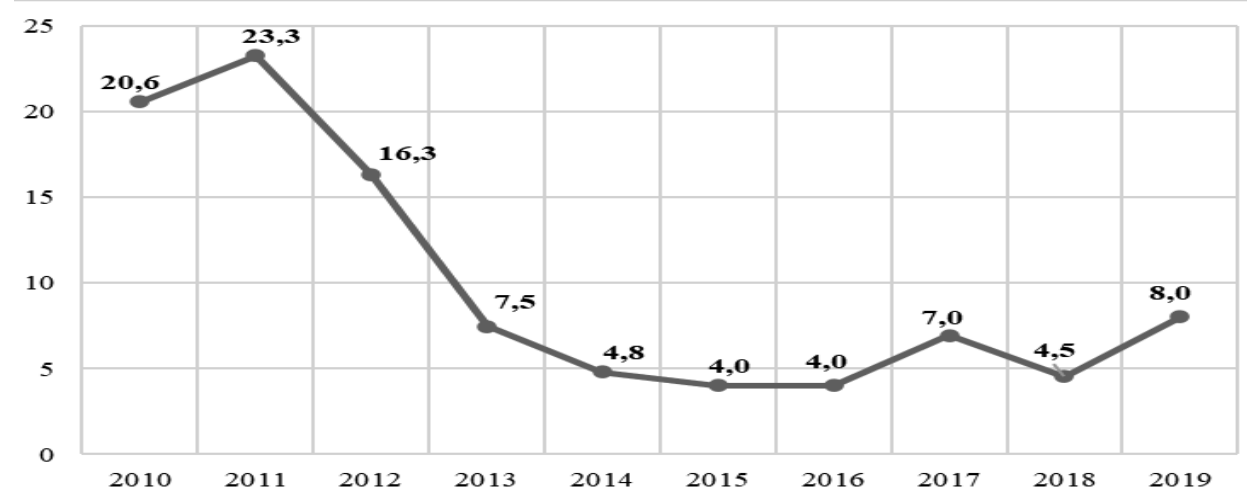

Author's research

As can be seen from the presented chart, the percentage of traffic accidents caused by psychoactive substances is declining (20.6\% in 2010 and $8.0 \%$ in 2019). The highest percentage of traffic accidents was in 2011 (23.3\%), and the lowest in 2015 and 2016 (4.0\%), after which there was a gradual increase in the period from 2017 to 2019. years. Presented results indicate undeniable 
influence of psychoactive substances on safe behaviour in traffic, as well as that there is a higher prevalence of registered exogenous characteristics (alcoholism and fatigue) as influential factors in traffic accidents compared to psychoactive substances as an influential factor in traffic accidents.

\section{Conclusion}

The results of empirical research have shown a significant impact of alcoholism, fatigue and psychoactive substances on the perception, abilities of drivers and other road users. In addition, exogenous characteristics have a direct impact on the safe behaviour of road users. In the Republic of Serbia in the period from 2010-2019, the number of traffic accidents in which the influential factor was an alcoholic condition has increased $(10.7 \%$ in 2010 and $12.0 \%$ in 2019). It is important to point out that in 2018 , the tolerance limit for alcoholism in traffic was reduced to 0.2 per mille (amendments to the ZoBS in 2018). By summarizing the results of research on the harmful effects of alcohol on the safe behaviour of drivers, the existence of consistent conclusions can be observed. In almost all quantities, alcohol leads to a reduction in the abilities necessary to perform complex driving tasks, hence it is considered one of the significant causes of traffic offenses. The data also show that in the analysed period, there was an increase in the share of fatigue as an influential factor in traffic accidents $(9.2 \%$ in $2010,14.01 \%$ in 2019$)$. The share of psychoactive substances as an influential factor in traffic accidents decreased from 2010 to 2017. However, compared to 2017 (4\%), there is an increase in $2019(8 \%)$ in the share of psychoactive substances as an influential factor in traffic accidents.

Based on the presented data, it is very important to point out that it is necessary to continuously work on improving traffic safety through the application of legal regulations and stricter sanctions within the penal policy for traffic offenses. In that sense, it is especially important to point out that the application of preventive measures can significantly increase the awareness of traffic participants and improve traffic safety. What is common to exogenous characteristics is the possibility that preventive measures such as education, campaigns, informing the public about the negative impact of these causes on safe driving, can significantly affect the goal of reducing the share of these causes in the total number of accidents. The development of modern technologies could contribute to the reduction of fatigue as an influential factor in traffic accidents. These technologies refer to various systems for monitoring driver behaviour while driving, which warn the driver in case of fatigue or deconcentration. 


\section{Petrović Aleksandra}

Doktor nauka, Univerzitet u Prištini - Fakultet tehničkih nauka u Kosovskoj Mitrovici, Srbija

\section{EGZOGENE KARAKTERISTIKE SAOBRAĆAJNIH DELINKVENATA}

REZIME: Egzogene karakteristike učesnika u saobraćaju, kao što su: alkoholisano stanje, umor i psihoaktivne supstance, imaju značajan uticaj na bezbedno ponašanje u saobraćaju, posebno vozača motornih vozila. $U$ tom smislu one predstavljaju faktore koji mogu neposredno da utiču na nebezbedno ponašanje u saobraćaju. Uticaj egzogenih karakteristika na bezbedno ponašanje učesnika u saobraćaju analiziran je na osnovu iskaza u dokumentima i rezultata brojnih empirijskih istraživanja. Za potrebe ovog rada prikupljeni su i analizirani statistički podaci o uticajnim faktorima saobraćajnih nezgoda za period 2010-2019. godine u Republici Srbiji. Nakon uvida u statističke podatke izvršena je kvalitativna i kvantitativna analiza sadržaja. Pored statističke metode prilikom istraživanja korišćene su i metode analize sadržaja, empirijski metod, deskriptivni metod, komparativne metode, kao i metode dedukcije i indukcije, kako bi se mogla izvršiti analiza kretanja trenda i zastupljenosti ovih uticajnih faktora saobraćajnih nezgoda u Republici Srbiji. Statistički podaci, koji su u ovom radu obrađivani, korišćeni su iz baze podataka Agencije za bezbednost saobraćaja Republike Srbije. Rezultati istraživanja pokazuju u kojoj meri egzogene karakteristike utiču na bezbedno ponašanje učesnika u saobraćaju, kao i na težinu posledica saobraćanih nezgoda. Posmatrane pojedinačno, navedene karakteristike imaju različit intenzitet uticaja na bezbedno ponašanje u saobraćaju. S tim u vezi od spoljašnjih karakteristika saobraćajnih delinkvenata, najveću zastupljenost ima alkoholisano stanje kao uticajni faktor, koji posebno utiče na žestinu saobraćajnih nezgoda u Republici Srbiji.

Ključne reči: saobraćajni delinkventi, saobraćajne nezgode, delikti, bezbednost saobraćaja. 


\section{References}

1. Atanacković, D., R., Lukić, M., Lazin, Đ., Milovanović, Z., \& Radulović, Lj. (1987). Krivična dela ugrožavanja javnog saobraćaja na putevima [Criminal offenses of endangering public traffic on the roads]. Novi Sad: Slavija-Press

2. Connor, J., Norton, R., Ameratunga, S., \& Jackson, R. (2004). The contribution of alcohol to serious car crash injuries. Epidemiology, 15 (3), pp. 337-344. Downloaded 2020, September 17 from https://scholar.google. $\mathrm{com} / \mathrm{scholar} ? \mathrm{hl}=\mathrm{sr} \&$ as_sdt $=0 \% 2 \mathrm{C} 5 \& \mathrm{q}=\mathrm{C}$ Connor $\% 2 \mathrm{C}+\mathrm{J} . \% 2 \mathrm{C}+$ Norton $\%$ $2 \mathrm{C}+\mathrm{R} . \% 2 \mathrm{C}+$ Ameratunga $\% 2 \mathrm{C}+\mathrm{S} . \% 2 \mathrm{C}+\mathrm{Jackson} \% 2 \mathrm{C}+\mathrm{R} .+\% 282004 \% 29$ . + The + contribution + of + alcohol + to + serious + car + crash + injuries. + Epide miology $\% 2 \mathrm{C}+15 \% 283 \% 29 \% 2 \mathrm{C}+\& \mathrm{btnG}=$

3. Dassanayake, T., Michie, P., Carter, G., \& Jones, A. (2011). Effects of benzodiazepines, antidepressants and opioids on driving: a systematic review and meta-analysis of epidemiological and experimental evidence. Drug Safety, 34 (2), pp. 56-143. DOI: https://doi.org/10.2165/11539050000000000-00000 https://pubmed.ncbi.nlm.nih.gov/21247221/

4. Baza podataka o saobraćajnim nezgodama [The database on traffic accidents]. Downloaded 2020, August 23 from https://www.abs.gov. rs/\%D1\%81\%D1\%80/analize-i-istrazivanja/baza-podataka.

5. Džunić, B. (2018). Preventivne aktivnosti u cilju sprečavanja i suzbijanja kriminaliteta sa osvrtom na strategijski okvir Republike Srbije [Preventive activities aimed at preventing and combating crime with the reference to the strategic framework of Republic of Serbia]. Pravo-teorija i praksa 35 (7/9), pp. 64-69. DOI: https://doi.org/10.5937/ptp1809054d

6. Hajduković, M. (1970). Uticaj uzajamnog delovanja stanja umora i alkoholisanosti [Influence of interaction of state of fatigue and alcoholism]. In: Zbornik radova Simpozijuma o prevenciji saobraćaja [Proceedings of the Symposium on Traffic Prevention]. Kragujevac

7. Horne, J. A., \& Reyner, L. A. (1995). Sleep related vehicle accidents. $B m j$, 310 (6979), pp. 565-567. DOI: https://doi.org/10.1136/bmj.310.6979.565

8. Lipovac, K. (2008). Bezbednost saobraćaja [Traffic safety]. Beograd: JP Službeni glasnik

9. Lyznicki, J. M., Doege, T. C., Davis, R. M., \& Williams, M. A. (1998). Sleepiness, driving, and motor vehicle crashes. Jama, 279 (23), pp. 1908 1913. DOI: https://doi.org/10.1001/jama.279.23.1908

10. Milić, A. (2007). Saobraćajna psihologija [Traffic psychology]. Doboj: Saobraćajno-tehnički fakultet 
11. NHTSA (1994). Computing a BAC estimate. Office of Program Development and Evaluation, National Highway Traffic Safety Administration. U.S. Department of Transportation, Washington, DC, pp. 4. Downloaded 2020, October 21 from https://crashstats.nhtsa.dot.gov/ Api/Public/Publication/94F1

12. NIAAA (1997). Ninth Special Report to the U.S. Congress on Alcohol and Health, National Institute on Alcohol Abuse and Alcoholism, US. Downloaded 2020, August 23 from https://pubs.niaaa.nih.gov/publications/aa38.htm

13. Petrović, A. (2019). Kretanje stope saobraćajne delinkvencije u Republici Srbiji [Trends in Traffic Delinquency Rates in the Republic of Serbia]. Pravo - teorija i praksa, 36 (10-12), pp. 45-56. DOI: https://doi. org/10.5937/ptp1910045p

14. Petrović, A. (2021). Efekti primene zakonske regulative na sprečavanje saobaćajnih delikata u Republici Srbiji: doktorska disertacija [Effects of application of legal regulations on prevention of traffic offenses in the Republic of Serbia: doctoral thesis]. Novi Sad: Pravni fakultet za privredu i pravosuđe Univerziteta Privredna akademija u Novom Sadu. Downloaded 2021, September 10 from https://nardus.mpn.gov.rs/ handle/123456789/18471

15. Petrović, A., Jovanović, D., \& Stanojević, P. (2020). Promene broja poginulih u saobraćajnim nezgodama u Republici Srbiji. Tehnika, 55 (4), pp. 479-483. DOI: https://doi.org/10.5937/tehnika2004479p

16. Ronen, A., Moed, Y., Gertner, R., Oron-Gilad, T., Cassuto Y., \& Shinar D. (2004). Subjective Feeling, Performance and Physiological Strain While Driving Under Alcohol Intoxication. Proceedings of the 17th International Conference on Alcohol, Drugs and Traffic Safety. Glasgow, UK, pp. 2-6. Downloaded 2020, September 3 from https://scholar.google.com $/$ scholar?hl=sr\&as_sdt $=0 \% 2 \mathrm{C} 5 \& \mathrm{q}=16 . \% 09 \mathrm{Ronen} \% 2 \mathrm{C}+\mathrm{A} . \% 2 \mathrm{C}+$ Moed $\% 2 \mathrm{C}+\mathrm{Y} . \% 2 \mathrm{C}+$ Gertner $\% 2 \mathrm{C}+\mathrm{R} . \% 2 \mathrm{C}+$ Oron-Gilad $\% 2 \mathrm{C}+\mathrm{T} . \% 2 \mathrm{C}+\mathrm{C}$ assuto + Y. $\% 2 \mathrm{C}+$ Shinar + D. $+\% 282004 \% 29 .+$ Subjective + Feeling $\% 2 \mathrm{C}+\mathrm{P}$ erformance+and + Physiological + Strain + While + Driving + Under+Alcohol + Intoxication. + Proceedings + of + the +17 th + International + Conference + on + Alcohol $\% 2 \mathrm{C}+$ Drugs + and + Traffic + Safety.+Glasgow $\% 2 \mathrm{C}+\mathrm{UK} \% 2 \mathrm{C} \& b t$ $\mathrm{nG}=$

17. Stanojević, P. (2013). Uticaj saobraćajne prinude na stavove i ponašanje vozača: doktorska disertacija [Influence of traffic enforcement on drivers' attitudes and behaviour: doctoral thesis]. Novi Sad: Univerzitet $\mathrm{u}$ Novom Sadu, Fakultet tehničkih nauka 
18. Stutts, J. C., Masten, S. V., Martel, C. A., \& Thomas, L. (2006). Predicting daytime and night time drowsy driving crashes based on crash and driver interview data. Highway Safety Research Center Final report to NHTSA. University of NorthCarolina, ChapelHill,NC.Downloaded2020, September 11 from https://one.nhtsa.gov/Research/Driver-Simulation-(NADS)/ COMPLETED-NADS-RESEARCH-REPORTS

19. Walsh, J. M., Johan, J., Asbjørg, S. C. \&, Alain, G. V. (2004). Drugs and driving. Traffic Injury Prevention, 5 (3), pp. 241-253. DOI: https://doi. org/10.1080/15389580490465292

20. Zakon o bezbednosti saobraćaja na putevima [Road Traffic Safety Act]. Službeni glasnik RS, br. 41/09, 53/10, 101/11, 32/13 - odluka US, 55/14, 96/15 - dr. zakon, 9/16- odluka US, 24/18, 41/18, 41/18 - dr. zakon, $87 / 18,23 / 19$ i 128/20 - dr. zakon 